Journal of the British Association for Chinese Studies, Vol. 9 (1), January 2019 ISSN 2048-0601

(C) British Association for Chinese Studies

\title{
Where to Belong? The Intersectionality of Discrimination Faced by Chinese Female Academics
}

Yan Wu

Swansea University

When web forums first emerged in China in the 1990s, an internet satire concerning women holding higher education credentials went viral almost overnight within online communities. This satire compared women holding higher education degrees to the three female prototypes in Louis Cha Jingyong's (Jin Yong 金庸) martial arts and chivalry (wuxia 武侠) novels. Bachelor degree holders were compared to "Little Dragon Maiden" (Xiao Longnü 小龙 女), an indifferent, but elegant and beautiful martial arts master who was loyal to her first and only love. Master's degree holders were compared to Li Mochou 李莫愁, a middle-aged martial arts master who morphed into a brutal killer after her lover betrayed her. PhD degree holders were compared to the elderly "Abbess Annihilation" (Miejue Shitai 灭绝师太), who was compelled to avenge the death of her lover and turned into a merciless man-hater and mankiller. In the novels, these three characters were rewarded or punished in narratives centring around their relationship to men-the youthful and loyal Little Dragon Maiden reunited with her lover eventually, while the other two characters (who happened to be much older and more experienced) were driven to their respective deaths due to their lack of love, despite their formidable martial arts power.

Ever since the late 1990s, this satire has been reposted, recycled, commented, discussed, and turned into memes-and it is still going strong online today. The

I would like to thank Prof Gerda Wielander (University of Westminster) for inviting me to write this article, and for her advice and patience during the course of writing. 
popularity of this satire in the past two decades, to a large degree, reflects a sustained sexist belief in Chinese society that single women with power, intelligence, and the wisdom that comes with age are dangerous. They should either be "converted" into wives for more powerful men (in the case of Little Dragon Maiden), or destroyed entirely if their power becomes too mighty to control. Some male internet users even summarised the unattractive features of female PhDs: they tend to be older than other eligible, single women; they tend to have a sense of superiority due to their academic achievements; and they tend to be scientific and unromantic.

In socialist China, the Communist Party adopted a form of "state feminism" in mobilising women, and brought them into the public arena. However, the Chinese Communist Party did not seriously confront the patriarchal system, upon which they gained the support from the peasantry and working class people (Stacey, 1983). The economic reform and the adoption of a socialist market economy from the late 1970s, on the one hand, provided women, alongside men, with opportunities to produce economic success; while on the other hand, the partial withdrawal of the state allowed the re-emergence of traditional patriarchal values which discriminated against, and excluded, women in education and employment (Rai, 1992). In the meantime, despite the rise of grassroots feminism in the country, Confucianism still plays a strong role, or has even enjoyed a renaissance. Women are still regarded as participants in sustaining sexist practices that conform to Confucian ideals in Chinese society. Being a highly-educated, strong-willed, self-determining individual is not an expectation for women.

Driven by various motivations, I came to the UK in 2002 to pursue a PhD degree. It seemed like a dream come true when I was offered an academic position with Swansea University immediately after graduation. My job involves teaching, research, and administration, just like my British colleagues who hold $\mathrm{PhD}$ degrees. Ever since gaining this employment, I have known, or worked with, many intelligent, ambitious, and aspiring young Chinese academics in the country. Among them, many either hold a PhD degree or are in the process of obtaining one. Starting an academic career after completing a PhD, if possible, outside of China, is on everyone's mind. When I wrote the title for this article, I recalled a voice from a few years ago, when a young woman confidently told 
me: "You did it; you proved that a Chinese woman can obtain a PhD, find a job, and have a family in this country. I could do the same." Hence it is almost my mission to share with these young people the unique intersectional experience of being Chinese, and female, in the British HE environment.

Britain has been several steps ahead of China in terms of safeguarding gender and racial equality in the workplace. The general public also holds a much more accepting attitude towards women with PhD degrees, and HE institutions, in particular, have made major progress towards ethnic diversity and gender equality in recent years.

On the surface, British universities have achieved a high level of gender equality. According to Higher Education Statistics, among the total number of 206,870 female and male academics holding permanent or fixed-term contracts in 2016-2017, 46\% of academic staff were women, who contribute to the prosperity of UK HE. Although male academic staff members outnumbered female academic staff members in general, at first glance, the discrepancies between genders are not significant in most areas. It is when we consider different types of work, and types of employment, that the differences become obvious. There are 1.3 times more male than female staff-members doing research; 1.6 times more men work in Teaching and Research than women. As a recent development, the University and College Union (UCU) has warned that

fixed-term and hourly paid staff are faced with job insecurity which blights our further and higher education systems, bringing with it inefficiency, inequality and personal stress. Alongside this, part-time staff are too frequently not being employed on pro-rata pay and terms and conditions of service (University and College Union, 2018).

The insecurity and inequality associated with part-time jobs seem to affect more women than men. The areas where female academic staff members dominate are mainly in part-time employment. In almost all types of part-time employment, female academics outnumber their male counterparts. Most notable is the part-time research-only contract, where female staff (combing 
both permanent and fixed-term contracts) account for more than two thirds (67\%) of the total.

In the same academic year (2016-2017), non-EU academic staff members accounted for $12.4 \%$ of the workforce-a minority that contributes to the global expansion of UK HE, and the internationalisation of British universities.

Being ethnic minorities, BME staff in general face more hurdles in career development compared to their white colleagues. There are no specific statistics about non-EU BME female staff members; hence, it is difficult to gauge the representation of this group at various levels. What I am discussing here is a unique intersectional experience from a small, yet growing, Chinese female academic community.

Firstly, Chinese female academics face the same barriers in their career development as their British counterparts. The gender pay gap, the lack of institutional childcare support, a male-dominated HE culture, and the lack of female leadership are all factors affecting female academics of different nationalities. I was lucky enough to be working in a university that has been actively reforming male-dominated $\mathrm{HE}$ culture, and has promoted a number of inspiring women to professorial and senior management positions in recent years. Nonetheless, changing the HE systematic structure is anything but easy. According to the UCU, the gender pay gap in the UK is the highest in the European Union; 36\% of female lecturers are paid in the bottom half of the 8 point spine, compared to $32 \%$ of male lecturers (University and College Union, 2018). There is no specific data concerning the position of non-EU female academics in the gender pay gap, but nonetheless, Chinese female academics are not excluded from this discrimination.

Although, in general, many EU countries boast a good work-family balance by offering state-subsidised childcare, the percentage of grandparents providing care for grandchildren has been on the rise. The UK has the second highest percentage of grandparents providing care for grandchildren among the 11 European countries studied, falling behind Sweden, the Netherlands, Denmark, France, Germany, Hungary, Portugal, Spain, and Italy (Glaser et al., 2013: 8). Compared with British or European female academics, Chinese female 
academics are less likely to seek support with childcare from extended families due to the geographic distance involved. Combining these two factors, it is not difficult to draw a connection: the generally inadequate childcare provision at most $\mathrm{HE}$ institutions means that the reasons contributing to the gender pay gap, such as interrupted careers due to child-birth or childcare, tend to affect Chinese female academics even more.

Secondly, racial discrimination is still experienced by Chinese academics working in Europe and North American HE institutions, although in these countries, overt discrimination is outlawed. In general, Europe is an open, tolerant, multicultural community, but on the other hand, ethnic minorities, in particular immigrants, face prejudice. This includes "persistent stereotyping, stigmatisation and discrimination at all levels of society" (Kamali, 2009: 1). Discrimination today most often takes the form of subtle or covert, or even unintentional or unconscious bias, which artificially creates boundaries between "us" and "them" due to differences in culture, religion, beliefs, practices, and so on. British $\mathrm{HE}$ institutions have a very tolerant and multicultural environment in general. However, the feeling of not being trusted or included is often felt by Chinese academics, both male and female, simply because of the country they come from.

On the one hand, no institution would deny the financial contribution made by growing numbers of students, research funds, and research opportunities coming from China. The rise of China has created unmissable recruitment, research and collaboration opportunities for UK HE, so much so that a Chinese female colleague told me she was given heavy teaching and administrative responsibilities associated with looking after Chinese students by her university, which left her little time or access to research. As she fears, such lack of research opportunities will lead to a lack of opportunities for future career development.

On the other hand, the rise of China as a world political, economic, and military power is often viewed with mixed feelings; these mixed feelings could be subconsciously reflected in the way Chinese individuals are treated. There seems to be a shared misunderstanding among many that if a Chinese individual has decided to stay in the UK for career development, s/he must be a political dissident who has fled to freedom and democracy. If $s /$ he is not a dissident but 
stays in the UK to develop his/her career, that decision itself is puzzling or could even be treated with suspicion.

In October of 2018, Michigan University unexpectedly closed its connection to the China Data Centre, which had been part of the University since 1997. The university spokesperson explained that the closure was due to an internal review, which revealed that the centre would have required the university to make costly repairs and upgrades. But the Chinese academic who heads the centre said that its financial status had been healthy (Leung, 2018). Even worse, several Chinese postgraduate students in the US were reported as having been arrested, allegedly for espionage. Within the UK, according to the BBC, "British security officials are particularly concerned about universities being targeted for research and intellectual property" since universities are regarded as "a soft target for economic espionage" (Corera, 2018). There has not been an equivalent crackdown on Chinese academics in the UK, although the overall mixed feelings toward China contribute to a distrust of Chinese academics in general. One frustrated colleague told me that her proposal to set up a China Research Centre within her university was not successful due to the fact that the senior management team did not like the idea of constructing a Chinese "ghetto".

Black feminist bell hooks wrote Ain't I a Woman (1987), examining how the intersectionality of gender and race put black women under systematic oppression by both white and black men, and by white women. I feel that this unnamed, and unspoken, intersectional experience felt by many Chinese female academics deserves a place in the public discussion about the HE sector. In the end, working in a British university has been our choice-due to a commitment to an academic career, a belief in the liberal culture cherished by British universities, or even a change in personal circumstances. Who knows? Whatever the case, this commitment, trust, and freedom in making personal choices should not be mistreated.

How would we position ourselves-Chinese female PhD degree-holders working in UK universities? Well, in Louis Cha's less known novel, Swordswoman Riding West on White Horse (Baima xiao xifeng 白马啸西风), he depicts the rare, strong, female protagonist Li Wenxiu 李文秀. Li is a Han orphan brought 
up among Kazakh people in Northwest China. The various strands of love and morality have pulled this remarkable swordswoman between the Han and the Kazakh, between the depraved and the righteous. By the end of the novel, she has won the battle and become the last woman standing. Surprisingly, the loveless Li was not punished by the narrative with death. Instead, the heroine was set free. She trespasses both worlds, from the Gobi desert to the south of the Yangtze River, with a sword in her hand and a white horse by her side. She savours both, belongs to both and owns both. Maybe, Li Wenxiu shows us a possible reality: that of capable women who have fought for what they choose in life, despite the fact that they, at the same time, have to be burdened with the prize they have paid for such autonomy.

\section{References}

Corera, Gordon (2018), “Looking for China's Spies”, BBC, December 19, available at: https://www.bbc.co.uk/news/resources/idt-sh/Looking_for_Chinas_ spies (accessed 25.01.2019).

Glaser, Karen, Debora Price, Eloi Ribe Montserrat, Giorgio di Gessa and Anthea Tinker (2013), "Grandparenting in Europe: Family Policy and Grandparents' Role in Providing Childcare", Grandparents Plus, available at: https://www.grandparentsplus.org.uk/Handlers/Download.ashx?IDMF=8d 76d811-b0df-4d2e-ac5b-a3be0ada97e2 (accessed 25.01.2019).

Higher Education Statistics Agency (2018a), "HESA Yearly Overviews 2016/17", Higher Education Statistics Agency, available at: https://www.hes a.ac.uk/data-and-analysis/staff/overviews?breakdown\%5B\%5D=583\&year =621 (accessed 25.01.2019).

Higher Education Statistics Agency (2018b), "Staff", Higher Education Statistics Agency, available at: https://www.hesa.ac.uk/data-and-analysis/staff (accessed 25.01.2019).

hooks, bell (1987), Ain't I a Woman, London: Pluto Press.

Kamali, Masoud (2009), Racial Discrimination: Institutional Patterns and Politics, London: Routledge.

Leung, Rachel (2018), "With Little Explanation, 'U' Abruptly Cuts Ties with China Data Centre", The Michigan Daily, October 3, available at: 
https://www.michigandaily.com/section/research/little-explanation-u-mabruptly-cuts-ties-china-data-center (accessed 25.01.2019).

Rai, Shirin (1992), "Watering Another Man's Garden: Gender, Employment and Education Reforms in China", 21-40, in Shirin Rai, Hilary Pilkington and Anne Phizacklea (eds.), Women in the Face of Change: The Soviet Union, Eastern Europe and China, London: Routledge.

Stacey, Judith (1983), Patriarchy and Socialist Revolution in China, Berkeley: University of California Press.

University and College Union (2018), "Fixed-Term, Part-Time and Hourly Paid Staff", University and College Union, October 25, available at: https://www.ucu.org.uk/fixed-term/ (accessed 25.01.2019).

University and College Union (2018), "The Gender Pay Gap in Further Education: 2016/17 Data Report", University and College Union, available at: https://www.ucu.org.uk/media/9410/The-gender-pay-gap-in-furthereducation-England-201617---full-report-May-18/pdf/ucu_fe-gender-paygap-2016-17_report_may181.pdf (accessed 25.01.2019).

Yan Wu is Senior Lecturer in Media and Communication at Swansea University. 